\title{
Landscape after genocide
}

\author{
James Riding \\ Newcastle University, UK
}

\begin{abstract}
The March of Peace (Marš Mira) is a 63-mile, three-day walk through eastern Bosnia organised in memory of the victims of the 1995 Srebrenica genocide and traces in reverse a death march. Marchers take a trail from Nezuk stopping at mass graves found along the way, arriving at the memorial cemetery in Potočari a day prior to the annual mass funeral for victims who have been recently exhumed. This paper charts the journey from death march to peace march and asks the reader to assess the efficacy of embodied memory-work and the ethical responsibility to undertake - and responsibilities when undertaking alternative memory-work in post-genocide landscapes and sites of mass murder, through a series of rhetorical shifts. A number of frames are enacted to challenge other more linear and conventional approaches, allowing the sociological and political productivity of engaging with post-genocide landscapes in a post-conflict state to emerge, referencing dissident forms of remembrance through the method of walking-with others while traversing this post-genocide landscape on foot. Travelling-with around 8000 mourners, some of whom were survivors of the death march, the aim here is not to simply describe what is taking place, rather the journey is undertaken in order to activate a space. A space within which I might engage with issues of landscape, conflict and memory in the context of their current discussion within cultural and political geography, genocide studies and memory studies, and more importantly to speak of genocide and a post-genocide landscape.
\end{abstract}

\section{Keywords}

Conflict, Memory, Landscape, Genocide, Srebrenica, Bosnia

\section{Corresponding author}

James Riding, School of Geography Politics and Sociology, Newcastle University

E-mail: james.riding@newcastle.ac.uk

\section{Acknowledgements}

The author would like to thank supportive colleagues in the Space and Political Agency Research Group/RELATE Centre of Excellence at Tampere University.

\section{Funding}

This research was supported by the Leverhulme Trust: Leverhulme Early Career Research Fellowship, New Regional Geographies (For Sarajevo) [grant number ECF 2013-638] 


\section{Introduction}

More than two decades have passed since Srebrenica, the name of a place in eastern Bosnia now synonymous with genocide, and in the most significant war crimes case in Europe since Nuremberg survivors await the verdict of the International Criminal Tribunal for the former Yugoslavia on Ratko Mladić. Mladić is charged with two counts of genocide and nine crimes against humanity and war crimes for his role in conflict in the former Yugoslavia, the war in Bosnia from 1992 to 1995, the siege of Sarajevo from 1992 to 1996, and the Srebrenica genocide in 1995. ${ }^{1}$ On November 22 2017, he is found not guilty on one charge, the extermination and ethnic cleansing of the Bosniak community from the territory of the western Balkan country in the name of a Greater Serbia but received a guilty verdict on each of the other counts, and is sentenced to life in prison. Mladić's trial was the last high-profile case before the International Criminal Tribunal for the former Yugoslavia, a United Nations court which changed the landscape of international humanitarian law, as it prepared to close on December 312017 at the end of its mandate, after hearing the testimony of almost 5000 witnesses and holding around 11000 trial days for more than two decades. ${ }^{2}$

The guilty verdict on November 222017 has given some sense of an ending to victims, but it has done little to heal the deeper traumas and gaping divides present in the post-conflict, post-genocide landscape. ${ }^{3}$ Srebrenica, the mass murder of over 8000 Bosniaks - and a number of Bosnian Croats - by Bosnian Serb forces and their Serbian allies in July 1995 on the basis of their identity, still casts a long shadow over Bosnia-Herzegovina. After twenty-four years, the remains of victims are still being found in mass graves and are re-buried annually in a mass funeral at the Srebrenica-Potočari Memorial and Cemetery for the Victims of the 1995 Genocide. ${ }^{4}$ Mladić's ideology remains in the 'apartheid cartography' of the divided state of Bosnia-Herzegovina on the ground and he is a hero for some, a general, yet for others he is a war criminal, the Butcher of Bosnia. ${ }^{5}$ Citizens continue to live in the folds that the war in Bosnia created, side by side, not together, in genocidal landscapes such as the emblematic Drina Valley, a watery borderland in the far east of Bosnia and west of Serbia. ${ }^{6}$ This densely wooded, undulating frontier bore the brunt of ethnic cleansing through a series of massacres from Zvornik to Višegrad, and runs alongside, is part of, and is the tragic backdrop to the later genocide perpetrated by Bosnian Serb forces in Srebrenica. ${ }^{7}$

Officially the war in Bosnia was brought to an end a matter of months after Srebrenica in December 1995 when the Dayton Agreement was signed in Paris. Preceded by an agreement between Bosniaks and Bosnian Croats signed in Washington in 1994, the country was separated into two political entities, the predominantly Bosnian Serb (Orthodox), Republika Srpska (Serb Republic), and the mainly Bosniak (Muslim) and Bosnian Croat (Catholic), Federacija Bosne i Hercegovine (Federation of Bosnia and Herzegovina). The Federacija Bosne i Hercegovine itself consists of ten autonomous cantons (five majority Bosniak, three majority Bosnian Croat, and two ethnically mixed) further dividing the country, and due to its strategic importance to all sides during the conflict, the Brčko District is a condominium that belongs to both Republika Srpska and the Federacija Bosne i Hercegovine. ${ }^{8}$ The peace agreement, initialled in Dayton, Ohio in late November 1995, included an annex on elections, refugees and displaced persons, public corporations, national monuments, regional stabilisation, human rights and a constitution, as well as agreeing the peace settlement and the inter-entity boundary line, and it facilitated peace after three-and-a-half years of conflict. ${ }^{9}$ Today, the Dayton Agreement holds Bosnia-Herzegovina together and protects the territorial integrity of the state, at the same time as separating it into distinct ethnic entities. If it were to be abolished a future independence referendum and secession from BosniaHerzegovina by Republika Srpska would likely take place, and could lead to a return to conflict. 
Yet as many have contended before, the Dayton Agreement confirmed ethnic division by defining the ethnic cleansing of the landscape of the southeast European country on the map, drawing a series of lines that have prevented Bosnia-Herzegovina from developing entirely beyond wartime divisions. ${ }^{10}$ As geographers Gerard Toal and Carl Dahlman argue in Bosnia Remade, The General Framework Agreement for Peace in Bosnia and Herzegovina also known as the Dayton Agreement, 'was more an armistice agreement than the blueprint for a sustainable state', meaning ethnic division is the result of the international community's efforts at the Dayton Peace Accords in Dayton, Ohio. ${ }^{11}$ Despite the agreement recognising the need for a comprehensive settlement to bring an end to the tragic conflict in the region, and desiring to contribute toward that end and to promote an enduring peace and stability, ${ }^{12}$ there remains over twenty years after the end of the war in Bosnia, a lack, a loss of a national imaginary beyond the lines drawn across the country by the Dayton Agreement, which was designed to be replaced. ${ }^{13}$ The cartographic idiosyncrasy of the framework agreement, which followed roughly the frontlines embedded into the landscape during the war in Bosnia, means Srebrenica is now located in the easternmost part of Republika Srpska, and the expelled, many remaining in exile, return fleetingly for memorial events. ${ }^{14}$

Following the verdict by the International Criminal Tribunal for the former Yugoslavia in November 2017 on Ratko Mladić, moves were made by those in power in the entity Republika Srpska to deny a 2004 government report on the 1995 Srebrenica massacre. In a bid to fuel ethnic tensions ahead of elections in Bosnia-Herzegovina in October 2018 lawmakers in Banja Luka, the de facto capital of Republika Srpska, asked the regional government to revoke a report which concluded that Bosnian Serb forces killed over 8300 people - the vast majority Bosniak - in and around Srebrenica during the war in Bosnia. The vote was initiated by President Milorad Dodik and is the latest mobilising of the traumatic past used by his ruling party to galvanise voters around an ongoing ethno-nationalist agenda. Twentyfour years after Srebrenica, the leader of Republika Srpska continues to reject rulings by two international courts, the International Criminal Tribunal for the former Yugoslavia and The International Court of Justice, which both stated the atrocity qualified as genocide. In response to these findings by two international courts, two new war commissions have been set up in Republika Srpska to examine wartime crimes in Sarajevo and Srebrenica, which have already been accused of revisionism, seeking to distort the truth and whitewash atrocities. ${ }^{15}$

Devoid of a truth commission, ${ }^{16}$ and with reconciliation left in the hands of citizens, activists, and artists in Bosnia-Herzegovina, ${ }^{17}$ the politicisation of memory and the concomitant matter of genocide denial mean transitional justice has stalled over the more than two decades post-Dayton. As such a more hopeful, just and democratic future seems far away while the war in Bosnia is not yet firmly located in the past. ${ }^{18}$ The sense of unease in the troubled present has given rise to a growing nostalgia for the socialist past in Bosnia-Herzegovina, a Yugo-nostalgia, a nostalgia for a lost socialist future shorn of ethnic division. ${ }^{19}$ In light of the ongoing struggle over memory in Bosnia-Herzegovina, the fight to shape the narrative of the war in Bosnia and indeed to cast in stone how the war in Bosnia is remembered, I resolved to travel to Srebrenica to consider the geographies of remembering and forgetting, the politics intertwined in the remembrance of the traumatic past, and the mobilisation of the past today wrought through the divided political landscape of Bosnia-Herzegovina. ${ }^{20}$ This journey to Srebrenica is the final route taken as part of a long-standing engagement with and commitment to Bosnia-Herzegovina via a series of excursions through the post-conflict, post-genocide landscape, and it is indeed the only site where this long-term project on memory, landscape, and conflict in Bosnia-Herzegovina could end. ${ }^{21}$

In the summer of 2015, I spent three days walking along a sixty-three mile trail through the densely wooded hills and undulating grassy landscapes of eastern Bosnia, from a starting point in Nezuk to Potočari, where the Srebrenica Genocide Memorial Cemetery is located. The cemetery, officially 
dedicated on September 202003 to the 8372 civilians murdered by Bosnian Serb forces from July 11 to July 16 1995, contains the remains of both male and female victims of several religions, though the majority of the victims recovered from mass graves are male, Bosniak, and Muslim. The walk to the cemetery retraced in reverse a journey made almost twenty years earlier to the exact date. An attempt to escape the genocidal massacre in besieged Srebrenica, a demilitarised United Nations safe area protected by Dutch peacekeepers, where refugees had initially sought safety. Abandoning their posts, Dutchbat troops were unable - and in part unwilling ${ }^{22}$ - to prevent the impending massacre as Bosnian Serb forces entered Srebrenica on the afternoon of July 11 1995. Sensing the disaster that was about to take place, at midnight on July 111995 a column of people assembled and they began the long walk over mountains and through forests surrounding Srebrenica in the hope of escaping. Hunted by heavily armed soldiers, unarmed and without shelter, many were picked off from the back of the group and the line began to disintegrate as people were gunned down in cold blood scrambling north and west to the safety of Nezuk. While back in Potočari, men and boys were rounded up and ruthlessly executed on Mladić's order before being dumped in mass graves, and women and girls were raped and killed as a systematic massacre ensued after the town of Srebrenica fell to Bosnian Serb forces. Five days and six nights passed before the first survivors of the death march - an army of ghosts ${ }^{23}$ - arrived in safe territory, when it became apparent that thousands had been killed during the journey.

This tortuous journey for survivors and the final journey for many has since been reclaimed and re-travelled as, The March of Peace (Marš Mira). Moving in the other direction marchers arrive a day prior to the annual mass funeral in Potočari for victims who have been located in mass graves, exhumed, and identified in the previous year through an intimate practice of re-dignification. ${ }^{24} \mathrm{I}$ joined the peace march in July 2015 to undertake a pilgrimage via mass graves with the grieving and the survivors returning to a place they once called home to remember the victims of genocide, and with a particular intellectual agenda in mind. ${ }^{25}$ The aim of the journey with around 8000 others, some of whom were survivors of the death march, is not to simply describe what is taking place, rather the journey is undertaken in order to activate a space. ${ }^{26} \mathrm{~A}$ space within which I might engage with issues of landscape, conflict and memory in the context of their current discussion within cultural and political geography, genocide studies and memory studies, and more importantly to activate a space in geographical research, which speaks of genocide and the life that is left after genocide in order to ask what landscape after genocide is and how it has come to be. ${ }^{27}$ Indeed to question whether this landscape in the aftermath of genocide is postgenocide or if the landscape is irrecoverably a landscape of genocide due to the ongoing trauma of survivors and the presence of victims yet to be found. ${ }^{28}$

In order to answer these unanswerable questions, the paper draws from the fragmentary and multiple philosophy of Jean-Luc Nancy and performs a simultaneous opening-on-to and distancing-from a post-genocide landscape, referencing dissident forms of remembrance through the methodology of walking-with, being-with, and seeing-with while traversing this landscape on foot. ${ }^{29}$ It considers not sociologically determined notions of mobility common in the new mobilities paradigm but rather mobilities and the humanities, the textual landscapes represented in regional literature about this landscape, and in other recent work in landscapes on more-than-representational theory, memory, self, and landscape, walking and memory in the city, memorials, places, and nostalgia, and trail-walking treading paths through landscapes in distant regions beyond this. ${ }^{30}$ Yet here the trail is cold and represents a mourning walk far removed from much of this work and is given a new political impetus here, and necessarily it deconstructs this previous work on the singular subject in landscape. As such the journey begins with a provocation which is, landscapes are not static entities but rather performed, multiple and in-becoming and the subject traversing the landscape is plural too. ${ }^{31}$ 
Engaging with the work of geographers, sociologists, and anthropologists on memory and conflict, the following sections ask the reader to assess the efficacy of embodied memory-work and the ethical responsibility to undertake - and responsibilities when undertaking - alternative memory-work in postgenocide landscapes and sites of mass murder. ${ }^{32}$ It does this through a series of rhetorical shifts, challenging other more linear and conventional approaches by positing landscape as a conflictual lens a lens through which to speak of genocide and conflict beyond the state. These shifts question the privileging of studies which present a distanced Western gaze upon this region known as the Balkans, and indeed the foregrounding of the authorial embodied subject in difficult and estranged landscapes simply prefaced by deconstructing positionality, stating a desire for peace, and an aim to create a single multi-ethnic state. ${ }^{33} \mathrm{~A}$ number of frames are enacted in what follows, an alternative memory-work allowing the sociological and political productivity of engaging with post-genocide landscapes in a postconflict state to emerge. ${ }^{34}$

\section{Prologue}

Before this journey concerned with memory and remembering in a post-genocide landscape can begin, it is important to acknowledge at the outset that commemorative practices, of course, often reflect and consolidate the interests of power, in so far as the past becomes leashed to the services of new state and nation building. ${ }^{35}$ Public memory is moulded by a variety of memorial images and spaces, and these memorials remember the past according to national myths, ideals and political needs. ${ }^{36}$ Memory, in this public sense, whether collective or individual, is never shaped in a vacuum; the motives of memory are never pure. ${ }^{37}$ Furthermore individual traumatic historical mourning is a phenomenological process, which is also inseparable from this wider geopolitical landscape, as the individual body is collectivised when mourning and wound into a national(ist) narrative. Those mourning are categorised and placed within the regional structure of the unsettled post-conflict landscape, feeding back into the simplistic flattening of the self as a geopolitical ethnic subject. Remembering, in this narrow sense, becomes a political act which continues to reinforce ethnic division.

Yet an alternative memory-work is taking place here, seeking to create a just future beyond the ethnic civic discourses of the past and present. There are memorial acts present which subtly upset official state memory, and the common understanding of collective memory and remembrance as set in stone. ${ }^{38}$ In an attempt to escape the context in which they occur - a country separated along ethnic lines - these acts of remembering are freed from their collective and nation-building capacities and are instead reclaimed by the more discrete, idiosyncratic valences of the individual voice. In the process, the body dehumanised by the traumatic event - has been recuperated by individuals who see it as necessary to the work of mourning. ${ }^{39}$ A vulnerability and susceptibility to violence and abuse is precisely why using the body to commemorate is a vital and powerful counter-narrative to the material representations reinforcing nationhood. Specifically, the bodily act of commemoration becomes a counterpoint to the tendency in post-conflict regions to constantly collectivise the individual voice, a voice that was perceived as 'animal howl' through a process of dehumanisation for those that reside in the mass grave. ${ }^{40}$

Yet there remains a will to create monuments, for the power of the monument lies in the fact that it appears everlasting, set in stone. Monuments, by themselves however, are of little value, mere stones in the landscape. ${ }^{41}$ This is a deterministic view of the monument and their meanings, and ignores a growing literature on non-human agencies in landscape and of the monument itself which through sociopolitical and spatial arrangements are additionally imbued with a national identity, or soul, via pilgrimages to these sites. ${ }^{42}$ Monuments, as such, seem to become the symbolic centre of a landscape, gathering in the past, affirming the righteousness of the nation itself. The landscape and the nation appear natural, 
intertwined in a sense of home, enabling the inhabitants to dwell in this territorial topographic structure. However, many monuments are inimical to meditative remembrance and shamefully lack the nerve to project the awful purpose of themselves. ${ }^{43}$ They are a betrayal of the dead: victims of an incapacity, century just past, to devise a commemorative mode - a century that, more than any other, needed such a mode. ${ }^{44}$ While monuments can also be twisted by those in power to serve a new political purpose, and equally future generations can imbue them with new meanings. The meaning of a monument is never set in stone. ${ }^{45}$ In the region with which this paper is concerned this is clear to see, as many monuments were systematically targeted and destroyed, leaving the giant organic concrete monuments built to commemorate World War II, the socialist revolution and the fight against fascism, in ruins, after the collapse of Yugoslavia. ${ }^{46}$

In addition to monuments such as the memorial site this paper arrives at, there are alternative forms of memorialisation taking place such as the peace march charted here and other examples of explorations of memorial landscapes beyond that which is set in stone, considering vernacular landscapes and memorials that challenge official narratives. ${ }^{47}$ These alternative monuments and subversions of existing monuments or memorial sites have the potential to reclaim and rewrite the post-conflict landscape, restructure the overbearing topographic structuring of the state, and can lead to a pivotal shift in civic discourse. ${ }^{48}$ Yet in the geopolitically fractured present-day landscape of Bosnia-Herzegovina there remain few common sites of commemoration or collective spaces to remember the victims of the war in Bosnia. Monuments that are present often remember only a single ethnic group, reinforcing the geopolitical categories that the murderers imposed upon their victims. ${ }^{49}$ People are remembered as Bosnian Serb, Bosnian Croat, or Bosniak, as Orthodox, Catholic, or Muslim. Not as fathers, mothers, daughters, or sons. ${ }^{50}$ As such remembering has become a political statement, while those mourning are enfolded within persistent ethnic and identitarian narratives. ${ }^{51}$ What is more, the identifications of bodily remains resulting from genocide are exhumed, counted, re-associated, managed and consecrated as ethnic remains, the executed person is an ethnic other in death and it is left to female artists and the Mothers of Srebrenica to harness traumatic events in order to announce a more hopeful politics in Bosnia-Herzegovina. ${ }^{52}$ Despite this hopeful gendered work there remain unmarked landscapes of violence, landscapes perhaps inhabited by survivors of genocide that are neither visited as sites of dark tourism nor memorialised as part of a state narrative. ${ }^{53}$ These bare sites, such as the unmarked death camps near Prijedor in northwest BosniaHerzegovina for example, share a common monumental absence with the killing fields of Cambodia. ${ }^{54}$

\section{Writing the landscape, 1.}

Almost three decades have passed since the beginnings of the collapse of Yugoslavia and yet the same question remains for many citizens of the former state - a socialist state that seemed to be out-of-place in the new Europe - that is, Why Bosnia? As Misha Glenny writes in the concluding chapter of The Fall of Yugoslavia, such obscenities people suffered are not of course a unique feature of Bosnia-Herzegovina in the late twentieth century, as many inhabitants of Rwanda, Liberia, Sudan, Somalia, Afghanistan, Chechnya, Georgia, inter alia, have all experienced first-hand. ${ }^{55}$ Yet the wars that devastated the former Yugoslavia, meant images of suffering became almost natural to everybody in the West, as they took place in a televisual era. ${ }^{56}$ During this conflict time, to show another picture beyond ancient ethnic hatreds, to share a reality far more complex than the one which the media exposed, was a task taken up by artists and writers living in the intimate places that were now being aired in living rooms across the globe. ${ }^{57}$

In the Balkans we can discern a regional landscape in Miljenko Jergović's melancholic, dreamlike collection of stories Sarajevo Marlboro, which relies on minute details such as the smoking of a cigarette to 
relay the devastation of the war in Bosnia. ${ }^{58}$ While Emir Suljagić's personal and painful Srebrenica memoir, Postcards from the Grave, gives much detail not just about life under siege but also facts which doubtless will be repeated in histories yet to be written. ${ }^{59}$ Equally we can detect a locating of memories in landscape in Slavenka Drakulic's $S$. A Novel about the Balkans, where through a series of flashbacks, S. relives the unspeakable crimes that she has endured, and in so doing tells her story. ${ }^{60}$ In a different register Aleksandar Hemon's The Book of My Lives, a collection of autobiographical narratives linked by their subject, a Sarajevan who moves from Sarajevo to Chicago is a struggle to reconcile his city and the Sarajevo he sees when he returns. ${ }^{61}$ Moreover in The Tiger's Wife, a novel set in a Balkan country mending from years of conflict Téa Obreht finds secrets bidden in the landscape itself. ${ }^{62}$ These regional texts speak back to Ivo Andrićs classic account Bosnian Chronicle set in the 'remote' town of Travnik, which presents the struggle for supremacy in a region that stubbornly refuses to submit to any outsider. ${ }^{63}$ Andrić uses his native Bosnia as a microcosm of human society, identifying the barriers of all kinds that hinder communication between individuals. Written against a background of violence in the region during World War II, the novel has renewed poignancy after the end of Europe's long twentieth century. ${ }^{64}$

In 1992, a seventeen-year-old Emir Suljagić was attempting to escape the ethnic cleansing of the Drina Valley by the Bosnian Serb Army and its Serbian allies. Together with his family he finds shelter as a refugee in the besieged enclave of Srebrenica. Srebrenica is now a town which gazes subsequently at nothing but its own past. It was once a thriving municipality, a spa town known for silver. Suljagić would go on to write a personal and painful memoir of his experiences in Srebrenica named Postcards from the Grave. ${ }^{65}$ Suljagić uses the idea of a postcard to write of the Srebrenica genocide deliberately. The very act of using the term, postcard, is infused with the politics of making something visible. A postcard is about bringing the addressee to the place you are, so they imagine the place. The addressee in this case was Europe, the behind-ness to the place Suljagić writes of is an act of genocide. In a war which was only decipherable to the rest of Europe through a simplified territorial identity politics, Suljagić wrote a postcard to the cosmopolitan Europeans who were desperate not to be mixed up in the war. ${ }^{66}$ Remnants left over, of the old eastern question, ${ }^{67}$ where the Balkans are viewed through a Western gaze as little more than a receptacle of savage nationalism despite decades of socialism. ${ }^{68}$

Suljagić's memoir complicates the European story, asking the cosmopolitan Europeans to remember the horrors of the Third Reich alongside the events that took place in the rural hinterlands of Bosnia-Herzegovina. He writes a postcard from the grave, to question what is deemed necessary to memorialise as part of the European story. ${ }^{69}$ Yet a postcard is a strange exchange of words. We do not expect a reply, but we still want it to be received and understood. You hope it arrives. As Jacques Derrida writes in The Post Card, the author is already no longer there, no longer responsible, absented in advance, leaving the document in your hands. ${ }^{70}$ It is an epigraphic fragment and metonymic, representing a relationship between people as much as the place they are sent from. This intimacy of human interaction is most important, here in Srebrenica, for Suljagić. Writing a postcard is a concentrated description of place and of being human, a moment of concentration and stillness. They are locked in time and located in place, but resonate into the future and travel elsewhere.

Deltiologists, as postcard collectors are called, collect for a variety of reasons though one of the most popular areas of collecting is town views - actual scenes from a particular town or region. This paper could be said to take a deltiological approach, through the lens of landscape, giving over a series of fragments or moments, collecting snatched impressions in the lived landscape. This was Suljagić's task too, capturing in the process an intimacy of human interaction in the most inhuman place imaginable. The mass grave was represented, with those citizens deprived of their human face acting as the senders of the 
postcard. ${ }^{71}$ Yet even with this dreadful task at hand, to give to the wider world the inhuman scenes that he witnessed in a discrete rural town in eastern Bosnia, Suljagić writes of love,

No one ever said, "I love you." Never did an open love declaration pass through those wires, aerials and cables. And yet nowhere and never had there been more love concentrated on one spot than in that half-dark, grey room with bars on the windows. ${ }^{72}$

\section{[INSERT FIGURE 1 HERE]}

Figure 1. Photograph of factory in Potočari.

Emir Suljagić escaped in 1995, while almost every man he had ever known subsequently lost their lives. A decade after the massacre, and sixty years after the liberation of Auschwitz, Suljagic writes of the survivor's guilt he experienced, which was identified among Holocaust survivors. ${ }^{73}$ Yet Suljagić's story is by no means a self-pitying tale of passive victims betrayed by the outside world. In Victims, Victims, Everywhere, Slavoj Žižek points out the inherent problem with the idea of victimhood as understood in humanitarian catastrophe,

The problem is, rather, that this... thoroughly de-politicises... intervention in humanitarian catastrophe [becomes], grounded in purely moral reasons, not an intervention in a well-defined struggle. ${ }^{74}$

As Gerard Toal puts it, mindless slaughter on formless ground. ${ }^{75}$ While via the de-politicised definition of humanitarian catastrophe that Žižek identifies in Bosnia-Herzegovina and elsewhere, victims remain victims post-conflict, protected in so far as one remains a victim; imbued with a voicelessness, subjected as an abject figure, the embodiment of 'bare life'. ${ }^{76}$

To remain no longer silent, no longer a victim, for a just future post-genocide, was Suljagić's political act. To write the terror of inequality after conflict, and caution against the reducing of identity to its degree zero was his task, all the while faced with a politics that aims to desensitise life to the terror of inequality in the newly neoliberal post-conflict, post-socialist western Balkans. ${ }^{77}$ It was a refusal to be bribed for silence, so one could never again exchange a body for its silence, and a manifesto for a nonexchangeable never commodified body was Suljagić's gift. ${ }^{78}$ A postcard from Srebrenica for life as nonequivalent, to become no longer a silent victim in a divided, ethno-nationalist, post-socialist, post-conflict era. $^{79}$

\section{Writing the landscape, 2 .}

Landscape after genocide, is a photograph attached to a barbed wire fence by a strand of string, an arrow pointing at a patch of earth, a bombed out house with gaping windows in the background, a feint barely perceptible trace of what was once a home, a brief outline of a past life, a ruin of blackened eroding concrete walls, a vale of suspiciously green grass. Landscape after genocide is the recurring images of a corpse embracing another corpse on a bridge over the Mijacka, it is sniper alley, decapitated mosques, a tunnel of hope, the Holiday Inn where journalists filed reports, dark tourist attractions. Landscape after genocide is a dimension-less point, a target frozen in a telescopic sight, no longer a sign on the way, or a sign in history, no longer a possible destination for business trips or illicit rendezvous, or the uncertain space for a fortuitous meeting or distracted wandering; this discrete place is simply a name, or a sign that grabs our attention, so that there will no longer be a landscape, but only a pure and naked identity. ${ }^{80}$ 
Landscape after genocide is ethnically cleansed proto-states, de facto states, statelets, entities, cantons, homogenous enclaves - it is such so that nothing else will get mixed in with it. ${ }^{81}$ Landscape after genocide is a Sarajevo rose filled with red resin, the destroyed Stari Most in the divided Mostar rebuilt as was, death camps in the Krajina buried beneath a mine, refugees crossing the Sava in a makeshift boat and never returning home, a sinister sports hall in Višegrad now part of a literary theme park. Landscape after genocide is the peeling wallpaper of the rape hotel in Foča, ripped curtains clinging to a few hooks, abandoned clothes hanging in a rotting cupboard, a crumpled photograph on a mantelpiece, muddied carpet, smashed up tiles, a pockmarked structure beside a mass grave - the expression of a complete system for the reduction to identity. ${ }^{82}$ It is a marble plaque, with a number denoting the amount of bodies concealed here, 506, and the word Srebrenica - the distinguishing of inscription from the effacement of a trace. ${ }^{83}$ It is Emir Suljagićs Postcards from the Grave, it is the landscape of the ethnically cleansed Drina Valley. ${ }^{84}$

Landscape after genocide, is a photograph of a skull, eye sockets almost filled with earth, a succession of winding branches poking out and around about it. Nature,

setting spiders to spin the winding-sheet and worms to fill in the grave, and grass to cover it pitifully up, adding flowers - as an unknown hand added them to the grave of Nero. ${ }^{85}$

\section{[INSERT FIGURE 2 HERE]}

Figure 2. Photograph of a mass grave.

It is the discrete site itself, a nondescript village in eastern Bosnia where MASOVNA GROBNICA, CR03, MASS GRAVE is dug into the earth, hidden under a mass of soil (Lokacija: Čančari - Kamenica, Klasifikacija: sekundama grobnica, Ekshumacija: 27.05. - 10.06.1998., Primarno: Kozluk - Pilica (juli 1995.), Broj Slučajeva: 158 slučajeva). Landscape after genocide is a photograph of a white UN truck, a white tarpaulin, a jumble of bodies, a watch, scraps of clothing, thighbones, a pelvis, skulls in churned up mud. It is the rural hinterlands of the same nondescript villages in eastern Bosnia, which conceal mass graves. It is MASOVNA GROBNICA, CR-13, MASS GRAVE (Lokacija: Čančari - Kamenica, Klasifikacija: sekundama grobnica, Ekshumacija: 13.10. - 22.01.2007., Primarno: Kozluk - Pilica (juli 1995.), Broj Slučajeva: 616 slučajeva).

Life after genocide as Damir Arsenijević writes is thus, the disassembling and reassembling of bones, sifting through the soil to landscape over the mass grave, to move the bodies to another grave. ${ }^{86}$ Life after genocide is a frantic search for missing persons, the counting of skulls to work out how many bodies are dumped in this clandestine location. Life after genocide is the work of the Missing Persons Institute of Bosnia and Herzegovina, the brushing and cleaning of bone fragments, DNA analysis, the finding and excavating of mass graves. It is the thousands of people reported missing at the end of the war in Bosnia. It is the remains of victims exhumed from hundreds of mass graves, it is the unaccounted for. Life after genocide is thus, the knowledge that you may have to bury a loved one only in part, missing limbs, perhaps missing a head. Life after genocide is a cleaved apart Frankenstein family, a photograph of a man wearing the JNA uniform, 'the uniform of the Yugoslav People's Army, the same army which took him away, killed him, and buried him in a clandestine mass grave ${ }^{97}$ His daughter, and her mother, 'were expelled from the Srebrenica region by the same army who then went after him in the woods', denoting the picture itself as life after genocide, 'the only monument the woman has, both to him and to the family'. 88 
The man in the photograph undertook a march of death through minefields, out of Srebrenica, fleeing the genocidal massacre. Survivors reversed and reclaimed this march itself, as, a march of peace. They return to the mass graves, to the site of genocide, travelling in the other direction, into the traumatic past. As we retraced a death march through the post-conflict landscape, through landscape after genocide, we witnessed a landscape that contains for survivors of genocide,

the excess of scattered bones, the dead-but-alive organic matter, whose smell builds up like a thin residue and clings to the top of your mouth. ${ }^{89}$

Those who survived the death march arrived in the safe territory of Nezuk days after setting off from Potočari, and many then travelled further to a nearby refugee camp in Tuzla to search for loved ones. On the morning of July 7 2015, almost exactly twenty years after the death march, we travelled from Tuzla to Nezuk for the start of a three-day walk in the other direction. The Marš Mira would begin the next day - a symbolic journey demonstrating the power of survivors of genocide commemorating atrocities through a marching performance of this genocidal landscape, what could be a viewed as, a gathering of the wounded..$^{90}$

\section{Writing the landscape, 3.}

Yellow tape wrapped around a succession of trees flanking a stony path. Lift the tape, bow the head and arch the back underneath the warning sign: pozor mine. Enter the minefield, still present here, a reminder of conflict in what appears at first glance to be a picturesque landscape. Prod, prod, prod with a thin branch, step, and twist the foot carefully on to the same spot that the stick was prodding the earth with. Repeat the process until we are called back, making sure to step in exactly the same points in the landscape as before. On our return, the train of humans begins to move again. A performing of the land, a rewalking of the journey made by survivors of the bloodiest episode of the war in Bosnia, fleeing genocide. An act of remembrance tied to an everyday struggle, stop genocide denial. Searing heat and shouts of hurry make this march anything but a leisurely pursuit, twisting up and down hills. Each day we would traipse towards our eventual destination, in and out of tree cover, providing scant relief. Each night we would set up camp. One night the weather was so bad that the tent collapsed, and we dragged it to an abandoned building, shelled out of existence. The concrete structure a reminder of life, shelled out of culture.

\section{[INSERT FIGURE 3 HERE]}

Figure 3. Photograph of a minefield.

Heidegger explains, 'The one who is unhomely always relates back to the homely, and can only do so by not attaining the homely'. ${ }^{91}$ This constant relating back for Heidegger is 'a forgetting as well as it is a remembering, ${ }^{92}$ Heidegger calls this relating back to the source, 'thoughtful remembrance', or the acknowledging that one belongs to a certain 'elsewhere. ${ }^{93}$ Yet here, walking-with survivors returning to the site of genocide, this is a land that is for them a home yet not, a scape that is homely yet not. A suspension of homeliness and unhomeliness occurs, and a suspension of presence and absence here prevents thoughts and feelings of both the homely and the unhomely. This temporal disjoint occurs through a suspension of time, rendering the present an ongoing conflict-time, which disrupts and displaces humans in the landscape. ${ }^{94}$ Survivors appear to be out-of-time, never fully-present in the landscape. 
The idea that feeling unhomely when travelling to foreign lands allows us to feel at home elsewhere, and one belongs to another landscape elsewhere, is a fundamentally difficult sentiment here. These lands are the landscapes that are supposed to be homely for those wandering-with, yet it is precisely these landscapes that are both uncannily and simultaneously, homely and unhomely. The landscape itself has been fundamentally altered in the consciousness of survivors. Yet as Julia Obert writes of Belfast, the space of the post-colonial or post-conflict landscape actually enables structures of subversion, insubordinate spatial practices; practices that refute authority by salvaging unpredictability, navigational tactics that allow a re-routing and re-rooting, at least in part, of their uncanny city. ${ }^{95}$ This is what could engender a dissident form of remembering, deconstructing the 'apartheid cartography' of the ethnically cleansed state of Bosnia-Herzegovina - without tearing up the Dayton Agreement. ${ }^{96}$

Arguably if we follow Heidegger's line of thinking here down the river, it implies that these landscapes can be a homeland. His homeland thinking can be twisted to justify ethnic cleansing, an ethnically defined living space all the way to the bloodiest bridge in the world, the bridge over the Drina in Višegrad. ${ }^{97}$ Yet in the unsettled post-conflict, post-genocide landscapes of Bosnia-Herzegovina, it is instead necessary to emphasise ideas of dislocation and distance, as an antidote to the vision of gathering and homecoming presented in Heidegger's Building Dwelling Thinking. ${ }^{98}$ As an antidote to the formulations of remembering witnessed in Bosnia-Herzegovina, where landscape, identity, and memory are enfolded within a national(ist) civic discourse, and mourning itself becomes a political act. Instead of articulating landscape as a gathering in which dwelling can blossom, instead of stressing any possible communion of being and location, landscape could here serve to index an incessant spacing, dispersal and distancing the antithesis of ethnic cleansing. ${ }^{99}$

How might this pathway for landscape research be taken up, John Wylie asks, if, 'the landscape, is the space of strangeness or estrangement'... 'The land of those who have no land, who have lost their way. ${ }^{100}$ A Heideggerian homely landscape could also be pushed further into the distance here, as Wylie suggests. ${ }^{101}$ The idea that there is a potential landscape elsewhere which is home, enables the creation of a landscape as a homeland, a claiming of space through marking the land itself. ${ }^{102}$ Yet if there are no original inhabitants, then there is no possibility of dwelling in a home-scape. ${ }^{103}$ This is a far more productive line of thinking in the unsettled post-conflict, post-genocide landscape, as it prevents the reducing of identity to its degree zero, and the cleansing of landscapes to include only those who are supposedly its rightful owners. The singular subject travelling through landscape, gathers it in, exerts power over it. ${ }^{104}$ There is a kind of violence involved in the creation of homely landscapes, a heritage formation which privileges certain views, certain bodies.

Subsequently, post-conflict landscapes have the potential to be reduced only to deathscapes or trauma-sites, or indeed, sanitised and sold as part of a depoliticised dark cultural heritage, and most divisively, claimed as part of a nationalist civic discourse. ${ }^{105}$ The problem here can be defined as ontopology, ${ }^{106}$ or what Wylie calls, homeland thinking. ${ }^{107}$ Building upon this unhomely reframing of landscape, the journey undertaken here remembers the kinds of ontopological accounts of the war in Bosnia that David Campbell identified and deconstructed twenty years ago. ${ }^{108}$ In contradistinction to a traditional geopolitical account and to counteract the ontopological urge, re-presented here are fragments of the past and present, for humans live and survive in stories and not the grand narratives of the historic record. Remembering conflict and writing a geopolitical account is often presented as a definitive, official narrative of the past, a record of the history of a landscape and conflict. In contrast, here it is demonstrated that there is a fragmentary demand when writing the disaster, and any account of a landscape and a conflict can never be truly complete. ${ }^{109}$ The figure of Parrhesiastes - the one who speaks 
the truth - haunts conflict storytelling, as words present only fragments of a past and present landscape, an excess put together only in part. ${ }^{110}$

It is for this reason too, that landscape is used here to write of genocide. The salience of landscape as a critical term instead involves modes of thinking and feeling that chafe against invocations of homeland as a site of existential inhabitation, as a locus of sentiment and attachment and a wellspring of identity. ${ }^{111} \mathrm{~A}$ landscape must be understood as a kind of dislocation or distancing from itself, as there are, after all, no original inhabitants. ${ }^{112}$ This negative reading of landscape drifts somewhat against a common phenomenological reading of landscape, ${ }^{113}$ where in which a 'building-up-to presence' occurs, through the summoning of 'ghostly presences' and the documenting of monuments and memorials in order to re-present the past. ${ }^{114}$ In post-conflict, post-genocide landscapes such as the unsettled present-day landscapes of Bosnia-Herzegovina, the writing of a spectral presence can in part sanitise the very real and painful corporeal traumatic past, leading to a speaking-for and an over-writing of the embodied practices that take-place in the landscapes themselves, after genocide. ${ }^{115}$ Defining a landscape in this ghostly way can in turn present the Balkans as a photographic negative of Europe, created through spectral representations of the Balkans and the ghosts of the past engender an inherently violent region, or Europe's repressed reverse. ${ }^{116}$

\section{Writing the landscape, 4.}

We sit and eat a packed lunch beside a mass grave, some smoke cigarettes; thick Bosnian coffee is poured from an embossed jug. A stone marks the spot where the mass grave lies, a sign warns people to slow down for a village where no village exists anymore. For three days we had travelled in the opposite direction to those who were forced to march, passing mass grave after mass grave and the bodies of victims yet to be found. The search for bodies is ongoing in the very woods we had just traipsed through. A bone hunter of Srebrenica has been walking rough-circles almost every day around Srebrenica for the past fifteen years or so, searching for human bones. He has identified more than 250 bodies, carefully scanning the ground, spotting half-buried remains under dirt. To the untrained eye, these remains look like a piece of wood, or something equally insignificant. Shuffling through the leaves in the forest above Srebrenica he comes across a leg, a jaw with teeth still attached, or another body part. More than twenty years have passed since the Srebrenica genocide yet the ground is covered in bones, missing human beings who failed to make their escape through the forest and remain in clandestine mass graves.

We waited in the garden of a home, our final stop after sixty-three miles of walking. A few moments later from above we could see the sinister factory and the beginnings of the memorial site, near the villages Donji Potočari and Gornji Potočari. Twenty years after genocide, the tenth march of peace had reached its final destination. The Srebrenica Genocide Memorial Cemetery, officially known as the Srebrenica-Potočari Memorial and Cemetery for the Victims of the 1995 Genocide, was now visible in the distance. Over 6600 victims recovered from mass graves have now been identified through DNA analysis and are re-buried here, the place we were now slowly descending towards. Twenty years prior to our arrival for the annual mass funeral, the massacre was imminent. After entering the besieged enclave with little resistance at 4.15pm on July 11 1995, Bosnian Serb forces led by Ratko Mladić moved into the safe zone and began to separate men and teenage boys from the rest of the crowd. Kneeling in lines with their hands behind their heads, many are shot dead on the spot or beaten to death. Blood spatters are still visible on a concrete wall in the factory opposite the memorial as we set up camp for a final time. Mass executions took place in hangars, factories, and houses in the vicinity of our last camp site before the bodies were loaded on to trucks and moved to primary, secondary and tertiary mass graves. ${ }^{117}$ Children were killed while their parents were forced to watch, rape, torture and disfigurement took place, 
corpses were dismembered, and the column of people set off through the undulating terrain that we had just traversed, with many never to be seen again.

I looked down at the lanyard that had been hanging around my neck for the past three days. Marš Mira 2015, Nezuk - Potočari, SREBRENICA 1995 - 2015, Da se ne zaboravi, Don't forget, 8372... Učesnik, Broj akreditacije, 3728. The number of dead, 8372, my number, 3728. Turning from the factory to the memorial site opposite we gazed at the neat lines of pristine white gravestones, which encouraged a certain way of walking and remembering. ${ }^{118}$ Walking lines, we looked down at the stones and away from the landscape in which they are placed, attempting to remember people. Avenues of names and dates, and the people who lived and died are laid out in a mathematical grid, as if this is a city of the dead, a necropolis. A wall of names, alphabetical, again gives over a sense of order. Rather than gathering in the landscape around about it and acting as a symbolic centre, the vast memorial makes apparent the fact that this is a land apart; it blasts apart a linear continuum of history, displaces, disrupts, dislocates, and resonates far into the future and elsewhere. ${ }^{119} \mathrm{It}$ is landscape after genocide, the unhomely, the inhuman, and the unnatural. We gaze upon the past as a single catastrophe and a history of the war in Bosnia appears as one single disaster. ${ }^{120} \mathrm{I}$ stand-with others viewing the horror of the epoch, flashing an eye-line to a single gravestone; the person in the grave a mute insistence deprived of a human face. ${ }^{121}$

\section{[INSERT FIGURE 4 HERE]}

Figure 4. Photograph of the memorial site.

The following day, Saturday July 11 2015, any sense of order was gone as new graves were dug, coffins were passed overhead, and thousands gathered to mark the twentieth anniversary of Europe's worst act of genocide since World War II. After spending the night in the shadow of the factory where executions took place, we crossed the road now lined with coaches and weaved around the press. We waited at the entrance gate for a while, before entering the memorial site. Once there, we sat beside a family waiting to bury their son, without his skull. A speech began, it was William J. Clinton, the President of the United States in 1995 who facilitated the Dayton Peace Accords, in Dayton, Ohio, and subsequently deployed thousands of American troops on Bosnian soil to help implement the Dayton Agreement. He spoke of his hope that this, Srebrenica, could never happen again, and then introduced the Prime Minister of Serbia, Aleksandar Vučić. Behind Vučić, now President of Serbia, a banner was held up with a slogan attributed to him daubed across it: For Every Killed Serb, We Will Kill 100 Muslims. Not before long, a crowd began surging towards the dignitaries stationed above the site, and stones and water bottles were thrown at Vučić, breaking his glasses.

Once rushed away in an armoured vehicle, the event was described as an assassination attempt. This violent act is symbolic of remembrance in the former Yugoslavia, where in which a conflict-time is ongoing and the traumatic past is still raw, not postmemory of future generations but trauma of survivors. ${ }^{122}$ In the weeks leading up to the twentieth anniversary of the Srebrenica genocide, Vučic said, "We should live in peace... If you want me and my offered hand I'm ready to come to Srebrenica on July 11", which he did despite calls for him to stay away. Immediately after, Vučić worked hard in order to achieve Russia's veto at the United Nations Security Council against the United Nations proclamation of the 1995 Srebrenica massacre, as genocide.

We had completed the march of peace, witnessed the visibly traumatised bury loved ones twenty years after their deaths, yet wondered what the future held for those who have lost their way, those who cannot reside in this unsettled landscape. Remembering Srebrenica as genocide, proclaiming Srebrenica, genocide, might have gone some way to building reconciliation in the troubled present. 


\section{Epilogue}

As witnessed in Srebrenica on Saturday July 11 2015, divergences in historical discourses and representations of the war in Bosnia between Yugoslavia's successor states are making it difficult to overcome past conflict. ${ }^{123}$ These troubled historical legacies are the very same ethno-nationalist myths and ideologies which first brought about the ending of Yugoslavia in the early 1990s. While present-day phenomena such as commemorations, apology and reconciliation in the post-conflict, post-genocide landscape are persistently enfolded within a certain ethno-nationalist civic discourse. At both a regional and a European level it is necessary to consider how co-existing narratives of the past are negotiated, and how as Europeans, the largely forgotten and disregarded story of the collapse of Yugoslavia is enfolded into the present European story, ${ }^{124}$ for it is indeed a tragic precursor to the authoritarianism, white nationalism and ethno-nationalism currently sweeping the globe. ${ }^{125}$ In addition at a regional level, texts such as Suljagić's Postcards from the Grave could be productively put to use, to contribute to cultural dialogue, mutual understanding and enhanced inter-comprehension between and in Yugoslavia's successor states. ${ }^{126}$

Along the route taken here intimate acts and objects of memory were witnessed and explored and these acts and objects are influenced, moulded, and enhanced by the geopolitical, the spatial, and the individual citizen. ${ }^{127}$ As in textual landscapes of regional literature, the affective capacity of memory becomes apparent, and through an alternative memory-work remembering moves beyond stoic, material and monumental representations of memory. ${ }^{128}$ In the literature referred to here the past can be imagined, and the war in Bosnia is remembered, commemorated and subverted through these affective interventions in the lived landscape. ${ }^{129}$ For as this unfolding paper gives over a sense of, in order to know, we must imagine for ourselves. ${ }^{130}$ The images, texts and performative memory-work of survivors have the agency to transport us not only to different times but also to different places. ${ }^{131}$ Memory as such, dislocates, despite (re)producing and maintaining an identity of the state(s), in its post-conflict nationbuilding capacity. Understanding the links between memory, identity, and landscape, can help us to comprehend the influence of a geopolitics of memory in the (re)production of the (post)conflict, (post)genocide landscape. ${ }^{132}$

Performative explorations of the memorial landscapes of post-conflict, post-genocide BosniaHerzegovina and the personal memory-work of survivors, activists, and artists are vital for building peace and reconciliation in the unsettled Dayton era. ${ }^{133}$ They are performances of the past where the exiled return to mourn and citizens make attempts to remember, locating memories in space, bringing them to bear productively on the troubled present. ${ }^{134}$ These performative explorations of memory offer specificities which diffract time and place, and via writing of and experiencing a marching performance of landscape, this paper exemplifies 'the possibilities of deploying a fragmentary and narrational rather than thematic or schematic structure', common in traditional geographic practice. ${ }^{135}$ Yet borrowing from a non-linear, unfolding, intimate and human format here, speaking of landscape after genocide, is not the long-established way to write of conflict and geopolitical struggle in the discipline of geography. Furthermore those deploying landscape as a critical term in human geography in a variety of regions and registers have been readily critiqued, accused of academic novelty, or of writing landscapes lacking politics and representing a masculinist Western gaze. ${ }^{136}$ These concerns are necessary to engage with, for landscape has perhaps been deployed too eagerly in order to write of the embodied travelling self - often in affluent Western locales - which can arguably gloss over the substantive nature of landscape itself and the politics of the state in which the landscape resides. ${ }^{137}$

In response to these concerns, landscape was instead used in this paper as a lens to reposition work on conflict within (political) geography beyond state theory, to refocus geographers on the bodily work 
of remembering and the memory-work of survivors in post-genocide landscapes, and most importantly to speak of injustice and trauma that necessarily yet persists in post-Dayton Bosnia while the war in Bosnia is not yet firmly located in the past. ${ }^{138}$ In addition this paper expands a long demonstrated interest in landscapes such as the landscapes of post-conflict, post-genocide Bosnia-Herzegovina, yet unlike what is set out here, these landscapes, the post-conflict landscapes that are written of, deal primarily with an idea that the present landscape is 'haunted' by the traumatic past. ${ }^{139}$ From the spectral scape, to the ghosts of place present in Karen Till's influential work on Berlin. ${ }^{140}$ To the material manifestations of memory and memorial-sites in the deathscapes of Avril Maddrell and James Sidaway's polemic edited collection. ${ }^{141}$ To the traumatic and psychoanalytic geographies of trauma in Jessica Dubow's extensive writings on Walter Benjamin and W.G. Sebald. ${ }^{142}$ This recent geographical work incorporates, as is undertaken here in part, a writing of the embodied practice of travelling through a post-conflict, post-genocide landscape. Yet in certain such accounts, a self-conscious making of the landscape is presented as a complex of resonances and sensibilities, spectral hauntings of the past, which go on to constitute the landscape when shuttling through it. ${ }^{143}$ In short, 'an imagination of, and a movement towards, presence'. ${ }^{144}$ It is instead perhaps interesting here to remember that this work itself is a situated understanding of haunting and to enact the alternative memory-work of anthropologist Anne Yvonne Guillou on the Cambodian genocide carried out by the Khmer Rouge regime, repositioning spirits not as Eurocentric hauntings but as otherthan-human beings who actively constitute the landscape. ${ }^{145}$

Enacting landscape in a post-conflict, post-genocide state took place in this paper, yet the fragmentary narrative performs a simultaneous opening-on-to and distancing-from a post-genocide landscape, for I simply do not have the right to write myself into this story. ${ }^{146}$ The journey taken intrinsically drifts somewhat against recent work on landscape in human geography where stress is often placed upon the central role of the geographer's bodily presence in the landscape - of sensuous, tactile and experiential being - in the co-constitution of self and landscape. ${ }^{147} \mathrm{~A}$ re-presenting of the past takes place, the dead summoned through the body of the geographer and the lives of those lost to conflict are re-presented. As such it appears as if the dead merely haunt the present with their spectral presence in the present-day post-conflict, post-genocide landscape. Yet in a vital political moment in the unsettled present, the dead invite us to blast this linear continuum of history open. ${ }^{148}$ Through their mute insistence, they invite us to bear witness to the corporeal traumatic past, and in so doing past injustices are made to bear productively on future struggles. ${ }^{149}$ In a move beyond the Derridean hauntology, where the figure of the ghost is presented as that which is neither present, nor absent, neither dead nor alive, here it is remembered that those who reside in the mass grave invite us not to re-present their lives as haunting presences. ${ }^{150}$ Rather it is the threat that they may disappear irretrievably within the mass grave, and are forgotten within the dominant, official history of the victor, which is necessary to emphasise here in landscape after genocide. ${ }^{151}$

Death sanctions this story, much like in Jacques Derrida's writings on haunting and mid-mourning which suggest a productive way of engaging with unresolved histories. ${ }^{152}$ Yet here I also contend that such sanctioning and spectral writing is not enough. I have attempted here for this reason, following Damir Arsenijević, to also speak of the life that is left after genocide, to speak of the corporeal remainder in landscape after genocide. ${ }^{153}$ This is the motive for the journey undertaken, an alternative memory-work in a post-conflict, post-genocide landscape, which Karen Till and Anna-Kaisa Kuusisto-Arponen recently called for geographers to undertake. ${ }^{154}$ A responsible geography of memory, ${ }^{155}$ bearing in mind the ethics and the politics of remembering and forgetting. ${ }^{156}$ 


\section{Notes}

${ }^{1}$ see for an important overview of Srebrenica remembrance post-genocide, L.J.Nettlefield \& S.E.Wagner, Srebrenica in the aftermath of genocide (New York: Cambridge University Press, 2014)

${ }^{2}$ see for information on the ICTY and justice, A.Jeffrey, The edge of law: legal geographies of a war crimes court (Cambridge: Cambridge University Press, 2019).

${ }^{3}$ see work on war tribunals, reconciliation, healing, and re-traumatising, J.N.Clark, International trials and reconciliation: assessing the impact of the International Criminal Tribunal for the Former Yugoslavia (London: Routledge, 2015); H.Cobban, Amnesty after atrocity? Healing nations after genocide and war crimes (London: Routledge, 2015); M.B.Dembour \& E.Haslam, 'Silencing hearings: victims witnesses at war crimes trials', European Journal of International Law, 15(1), 2004, 151-177; A.Jeffrey \& M.Jakala, 'The hybrid legal geographies of a war crimes court', Annals of the Association of American Geographers, 104(3), 2014, 652-667; K.R.Lanegran, 'Truth commissions, human rights trials, and the politics of memory', Comparative Studies of South Asia, Africa, and the Middle East, 25(1), 2005, 111-121.

${ }^{4}$ The author submitted a revised version of this paper in July 2019 when thirty-three victims were buried in the memorial site in Potočari, twenty-four years after genocide.

${ }^{5}$ see D.Campbell, 'Apartheid cartography: the political anthropology and spatial effects of international diplomacy in Bosnia', Political Geography, 18(4), 1999, 395-435; J.Crampton, 'Bordering on Bosnia', GeoJournal, 39(4), 1996, 353-361.

${ }^{6}$ see J-L.Nancy, Being singular plural (Palo Alto, CA: Stanford University Press, 2000).

${ }^{7}$ see B.Lasheras, Bosnia in limbo: testimonies from the Drina river (Hannover: Ibidem, 2018).

${ }^{8}$ see for information on the strategic importance of Brčko, A.Jeffrey, 'Building state capacity in postconflict Bosnia and Herzegovina: the case of Brčko District', Political Geography, 25, 2006, 203-227.

9 see A.Jeffrey, The improvised state: sovereignty, performance and agency in Dayton Bosnia (London: Wiley Blackwell, 2013).

${ }^{10}$ see Cambell, Apartheid cartography; Jeffrey, The improvised state; see also the cartographic work of the artist Mladen Miljanović and in particular Welcome to Bosnia, an image of the artist stood on a stool with an outline of the map of Bosnia-Herzegovina hanging over him like a noose; J.Riding, 'Representing a divided place: the artistic-military practice of Mladen Miljanović', Cultural Geographies, 24(1), 2017, 171 180.

${ }^{11}$ see G.Toal \& C.Dahlman, Bosnia remade: ethnic cleansing and its reversal (Oxford: Oxford University Press, 2011), p. 308.

12 access the Dayton Peace Agreement here: https://www.osce.org/bih/126173.

${ }^{13}$ see E.Gordy, 'Dayton's Annex 4 Constitution at 20: political stalemate, public dissatisfaction and the rebirth of self-organisation', Southeast European and Black Sea Studies, 15(4), 2015, 611-622.

${ }^{14}$ see for information on returnees and those who remain in exile, Toal \& Dahlman, Bosnia remade.

${ }^{15}$ the Srebrenica commission is headed by a professor of Jewish and Israeli History at the University of Texas, Gideon Greif, and the Sarajevo commission is headed by Rafael Israeli, an Israeli academic and professor at the Hebrew University of Jerusalem.

${ }^{16}$ see J.N.Clark, 'Does Bosnia need a truth and reconciliation commission? Some reflections on its possible design', Ethnopolitics, 12(3), 2013, 225-246; J.Dragović-Soso, 'History of a failure: attempts to create a national truth and reconciliation commission in Bosnia and Herzegovina, 1997-2006', International Journal of Transitional Justice, 10(2), 2016, 292-310.

${ }^{17}$ see J.Riding, 'A new regional geography of a revolution: Bosnia's Plenum movement', Territory, Politics, Governance, 6(1), 2018, 16-41 
${ }^{18}$ see Riding, A new regional geography of a revolution; Jeffrey, The edge of law.

${ }^{19}$ see S.Boym, The future of nostalgia (New York: Basic Books, 2001); J.Derrida, Spectres of Marx (Oxford: Routledge, 1994); P.Kolstø, 'Identifying with the old or the new state: nation-building vs. Yugonostalgia in the Yugoslav successor states', Nations and Nationalism, 20(4), 2014, 760-781; M.Todorova \& Z.Gille (Eds.) Post-communist nostalgia (New York: Berghahn, 2010); M.Velikonja, 'Lost in translation: nostalgia for socialism in post-socialist countries', East European Politics and Societies: and Cultures, 23(4), 2009, 535-551.

${ }^{20}$ see O.J.Dwyer \& D.Alderman, Civil rights memorials and the geography of memory (Athens: University of Georgia Press, 2008); S.Legg, 'Reviewing the geographies of memory/forgetting', Environment and Planning A, 39, 2007, 456-466; J.Riding, The geopolitics of memory: a journey to Bosnia (Hannover: Ibidem Press, 2019). ${ }^{21}$ see J.Riding, 'Landscape, memory, and the shifting regional geographies of northwest BosniaHerzegovina', GeoHumanities, 1(2), 2015, 378-397; J.Riding, 'Geographical testimony: a short history of a Yugoslav family', Journal of Cultural Geography, 34, 2017, 250-267; J.Riding, 'Writing place after conflict: exhausting a square in Sarajevo', GeoHumanities, 3(2), 2017, 431-450; J.Riding \& J.Wake-Walker, 'Towards a cultural geopolitics: on the making of a documentary-poetry film about a post-conflict place', Fennia, 195(1), 2017, 61-84; Riding, Representing a divided place; Riding, A new regional geography of a revolution; Riding, The geopolitics of memory.

${ }^{22}$ see the artwork Bosnian Girl by Šejla Kamerić created from graffiti sprayed on the wall of barracks in Potočari in 1994/95 by a Dutch UN peacekeeper.

${ }^{23}$ reporters at the time described "an army of ghosts" arriving in Tuzla.

${ }^{24}$ see E.Henderson, C.Nolin \& F.Pecerelli, 'Dignifying a bare life and making place through exhumation: Coban CREOMPAZ former military garrison, Guatemala', Journal of Latin American Geography, 13(2), 2014, 97-116; P.Moss \& C.Donovan (Eds.), Writing intimacy into feminist geography (London: Routledge, 2017); R.Pain, 'Intimate war', Political Geography, 44, 2015, 64-73; L.Renshaw, Exhuming loss: memory, materiality and mass graves of the Spanish civil war (London: Routledge, 2011).

${ }^{25}$ see work on pilgrimage, J.Eade \& .J.Sallnow, Contesting the sacred: the anthropology of pilgrimage (Chicago: University of Illinois Press, 1991)

${ }^{26}$ see G.Toal, 'An anti-geopolitical eye: Maggie O’Kane in Bosnia, 1992-1993', Gender, Place and Culture, 3(2), 1996, 171-186, p.171.

${ }^{27}$ see for previous work in geography on landscape and genocide in Cambodia, J.A.Tyner, G.B.Alvarez \& A.R.Colucci, 'Memory and the everyday landscape of violence in post-genocide Cambodia', Social and Cultural Geography, 13(8), 2012, 853-871; J.A.Tyner, 'Dead labor, landscapes, and mass graves: administrative violence during the Cambodian genocide', Geoforum, 52, 2014, 70-77.

${ }^{28}$ see Nettelfield \& Wagner, Srebrenica in the aftermath of genocide.

${ }^{29}$ see J-L.Nancy, Being singular plural; J-L.Nancy, The ground of the image (New York: Fordham University Press, 2005); J.Wylie, 'Landscape, absence, and the geographies of love', Transactions of the Institute of British Geographers, 34(3), 2009, 275-289.

30 see A.Blunt, 'Collective memory and productive nostalgia: Anglo-Indian home-making at McCluskieganj', Environment and Planning D: Society and Space, 21, 2003, 717-738; P.Cloke \& E.Pawson, 'Memorial trees and treescape memories', Environment and Planning D: Society and Space, 26, 2008, 107-122; C.DeSilvey, 'Observed decay: telling stories with mutable things', Journal of Material Culture, 11, 2006, 318338; C.DeSilvey, 'Salvage memory: constellating material histories on a hardscrabble homestead', Cultural Geographies, 14, 2007, 401-424; J.Dubow, 'The mobility of thought: reflections on Blanchot and Benjamin', Interventions: The Journal of Postcolonial Studies, 6, 2004, 216-228; T.Edensor, Industrial mins: space, aesthetics, materiality (Oxford: Berg, 2005); S.Hoelscher \& D.Alderman, 'Memory and place: geographies of a critical relationship', Social and Cultural Geography, 6, 2004, 347-355; N.C.Johnson. 'Locating memory: tracing the 
trajectories of remembrance', Journal of Historical Geography, 33, 2005, 165-179; S.Legg, 'Contesting and surviving memory: space, nation and nostalgia in Lieux de Memoire', Environment and Planning D: Society and Space, 23, 2005, 481-504; H.Lorimer, 'Cultural geography: the busyness of being 'more-thanrepresentational", Progress in Human Geography, 29, 2005, 83-94; H.Lorimer, 'Herding memories of humans and animals', Environment and Planning D: Society and Space, 24, 2006, 497-518; O.Mason, Walking the Line: Culture, Politics, and Movement on the Jordan Trail (University of Durham: Unpublished Thesis, 2019); D.Pinder, 'Ghostly footsteps: voices, memories and walks in the city', Ecumene, 2001, 81-91; J.Riding, 'A geographical biography of a nature writer', Cultural Geographies 23(3), 2016, 387-399; J.Riding, Land writings: excursions in the footprints of Edward Thomas (Newcastle: CSP, 2019); J.Spinney, 'A sense of place: and ethnography of kinaesthetic sensuous experiences of cyclists on Mt Ventoux', Environment and Planning D: Society and Space 24, 2006, 709-732; J.Wylie, 'An essay on ascending Glastonbury Tor', Geoforum 33, 2002, 441-454; J.Wylie, 'A single day's walking: narrating self and landscape on the South West Coast Path', Transactions of the Institute of British Geographers, NS 30, 2005, 234-247.

${ }^{31}$ see J-L.Nancy, Being singular plural.

${ }^{32}$ see C.Bennett, 'Living with the dead in the killing fields of Cambodia', Journal of Southeast Asian Studies 49(2), 2018, 184-203; D.P.Dixon, M.Pendleton \& C.Fearnley, 'Engaging Hashima: memory work, sitebased affects, and the possibilities of interruption', GeoHumanities 2(1), 167-187; M.Hirsch \& N.K.Miller (Eds.), Rites of return: diaspora poetics and the politics of memory (New York: Columbia University Press, 2011); N.C.Johnson, 'The contours of memory in post-conflict societies: enacting public remembrance of the bomb in Omagh, Northern Ireland', Cultural Geographies 19(2), 2012, 237-258; J.A.Tyner, Landscape, memory and post-violence in Cambodia (London: Rowman \& Littlefield, 2017); J.M.Selimovic, 'Making peace, making memory: peacebuilding and politics of remembrance at memorials of mass atrocities', Peacebuilding 1(3), 2013, 334-348.

${ }^{33}$ see for work on peace, S.Koopman, 'Let's take peace to pieces', Political Geography 30(4), 193-194; see for work on Balkanism, V.Goldsworthy, Inventing Ruritania: the imperialism of the imagination (London: Yale University Press, 1998); M.Todorova, Imagining the Balkans (Oxford: Oxford University Press, 1997).

${ }^{34}$ see J.Butler, Frames of war: when is life grievable? (London: Verso, 2010); W.G. Sebald, On the natural history of destruction (London: Hamish Hamilton, 1999); J.Wylie, 'Depths and folds: on landscape and the gazing subject', Environment and Planning D: Society and Space 24(4), 2006, 519-535.

${ }^{35}$ see R.S.Esbenshade, 'Remembering to forget: memory, history, national identity in postwar EastCentral Europe', Representations, 49, 1995, 72-96; W.Hung, 'Tiananmen Square: a political history of monuments', Representations, 35, 1991, 84-117; J.E.Young, The texture of memory: Holocaust memorials and meaning (New Haven: Yale University Press, 1993).

${ }^{36}$ see D.Ben-Amos \& L.Weissberg, Cultural memory and the construction of identity (Detroit, MI: Wayne State University Press, 1999); J.K.Olick (Ed.), States of memory: continuities, conflicts, and transformations in national retrospection (Durham, North Carolina: Duke University Press, 2003).

${ }^{37}$ see Young, The texture of memory, p. 2; C.Tilley, The materiality of stone: explorations in landscape phenomenology (Oxford: Berg, 2004); J.T.Johnson \& S.C.Larsen Being together in place: indigenous coexistence in a more than buman world (Minneapolis: University of Minnesota Press, 2017); S.Whatmore, Hybrid geographies: natures cultures spaces (London: Sage, 2002).

${ }^{38}$ see Riding, Landscape, memory, and the shifting regional geographies of northwest Bosnia-Herzegovina.

${ }^{39}$ see Butler, Frames of war.

${ }^{40}$ see D.Arsenijević, 'Mobilising unbribable life', in A.Mousley (Ed.) Towards a new literary humanism (Basingstoke: Palgrave Macmillan, 2011), pp. 166-181.

${ }^{41}$ see Young, The texture of memory, p. 2. 
${ }^{42}$ see Tilley, The materiality of stone; Johnson \& Larsen, Being together in place; Whatmore, Hybrid geographies.

${ }^{43}$ see Sebald, On the natural history of destruction.

${ }^{44}$ see M.Mazower, Dark continent: Europe's twentieth century (London: Penguin, 1999).

${ }^{45}$ see Young, The texture of memory, p. 3.

${ }^{46}$ see the work of the art-collective Grupa Somenik and their attempts to reclaim these forgotten monuments; D.Niebyl, Spomenik monument database (London: Fuel, 2018); Riding, Landscape, memory, and the shifting regional geographies of northwest Bosnia-Herzegovina.

${ }^{47}$ see Riding, Landscape, memory, and the shifting regional geographies of northwest Bosnia-Herzegovina.

${ }^{48}$ see M.Bal, J.Crewe \& L.Spitzer, Acts of memory: cultural recall in the present (Hanover, NH: Dartmouth College Press, 1998).

49 see F.Bieber, Post-war Bosnia: ethnicity, inequality and public sector governance (Basingstoke: Palgrave Macmillan, 2006); J.Edkins, Trauma and the memory of politics (Cambridge: Cambridge University Press, 2003).

${ }^{50}$ see Bieber, Post-war Bosnia.

${ }^{51}$ see D.Campbell, National deconstruction: violence, identity, and justice in Bosnia (Minneapolis: University of Minnesota Press, 1998).

${ }^{52}$ see Kamerić, Bosnian Girl; D.Arsenijević, 'Gendering the bone: the politics of memory in Bosnia and Herzegovina', Journal for Cultural Research, 15(2), 2011, 193-205.

${ }^{53}$ see the artwork Four Faces of Omarska by artist Milica Tomić, which remembers these unmarked death camps and the story of the journalist who uncovered them, E.Vulliamy, Seasons in hell: understanding Bosnia's war (New York: St. Martin's Press, 1994); Riding, Landscape, memory, and the shifting regional geographies of northwest Bosnia-Herzegovina.

${ }^{54}$ see Bennett, Living with the dead in the killing fields of Cambodia; Tyner, Alvarez \& Colucci, Memory and the everyday landscape of violence in post-genocide Cambodia; Tyner, Dead labor, landscapes, and mass graves: administrative violence during the Cambodian genocide; Tyner, Landscape, memory and post-violence in Cambodia.

${ }^{55}$ see M.Glenny, The fall of Yugoslavia (London: Penguin, 1992).

${ }^{56}$ see F.Guerin \& R.Hallas (Eds.), The image and the witness: trauma, memory and visual culture (London: Wallflower Press, 2007); D.Rieff, Slanghterhouse: Bosnia and the failure of the West (London: Vintage Random House, 1995); S.Sontag, Regarding the pain of others (London: Penguin Books, 2003).

${ }^{57}$ see Vulliamy, Seasons in hell.

${ }^{58}$ see M.Jergović, Sarajevo Marlboro (Brooklyn, NY: Archipelago Books, 2004).

${ }^{59}$ see E.Suljagić, Postcards from the grave (London: Saqi Books, 2005).

${ }^{60}$ see S.Drakulić, S. A novel about the Balkans (London: Penguin, 2001).

${ }^{61}$ see A.Hemon, The book of my lives (London: Picador, 2013).

${ }^{62}$ see T.Obreht, The tiger's wife (London: Phoenix, 2011).

${ }^{63}$ see I.Andrić, Bosnian chronicle (New York, NY: Knopf, 1963).

${ }^{64}$ see Mazower, Dark continent.

${ }^{65}$ see Suljagić, Postcards from the grave.

${ }^{66}$ see Nancy, Being singular plural.

${ }^{67}$ see Goldsworthy, Inventing Ruritania; Todorova, Imagining the Balkans.

${ }^{68}$ see S.Žižek, The fragile absolute: or why is the Christian legacy worth fighting for? (London: Verso, 2000).

${ }^{69}$ see G.Snel, 'The past is always in the present. Aether and the returns of history and Europe's new post1989 peripheries. The cases of Mihail Sebastian's diary and Emir Suljagić's Srebrenica memoir', Neohelicon, 41(1), 2014, 241-246. 
${ }^{70}$ see J.Derrida, The post card: from Socrates to Freud and beyond (Chicago, IL: University of Chicago Press, 1987).

${ }^{71}$ see S.Felman, The juridical unconscious: trials and traumas in the twentieth century (Cambridge, Massachusetts: Harvard University Press, 2002).

${ }^{72}$ see Suljagić, Postcards from the grave, p. 48.

${ }^{73}$ see C.Caruth (Ed.), Trauma: explorations in memory (Baltimore, MD: Johns Hopkins University Press, 1995).

${ }^{74}$ see Žižek, The fragile absolute, p. 57.

${ }^{75}$ see Toal, $A$ an anti-geopolitical eye.

${ }^{76}$ see G.Agamben, Homo sacer. Sovereign power and bare life (Palo Alto, CA: Stanford University Press, 1998).

${ }^{77}$ see C.Bennett, Bosnia's paralysed peace (New York: Oxford University Press, 2016); S.Horvat \& I.Štiks (Eds.), Welcome to the desert of post-socialism: radical politics after Yugoslavia (London: Verso, 2015); Jeffrey, The improvised state; Toal \& Dahlman, Bosnia remade.

${ }^{78}$ see Arsenijević, Mobilising unbribable life.

${ }^{79}$ see Campbell, Apartheid cartography; Crampton, Bordering on Bosnia; Gordy, Dayton's annex 4 constitution at 20; Horvat \& Štiks, Welcome to the desert of post-socialism.

${ }^{80}$ see Nancy, Being singular plural, p. 145.

${ }^{81}$ see Nancy, Being singular plural, p. 145.

${ }^{82}$ see Nancy, Being singular plural, p. 145.

${ }^{83}$ see J.Derrida, The beast and the sovereign, volume 1. (Chicago, IL: University of Chicago Press, 2009).

${ }^{84}$ see Suljagić, Postcards from the Grave; Derrida, The post card.

${ }^{85}$ see E.Thomas, The south country (London: J.M. Dent \& Sons Limited, 1909), p. 99.

${ }^{86}$ see Arsenijević, Mobilising unbribable life, pp. 166-167.

${ }^{87}$ see Arsenijević, Mobilising unbribable life, pp. 166-167.

${ }^{88}$ see Arsenijević, Mobilising unbribable life, pp. 166-167.

${ }^{89}$ see Arsenijević, Mobilising unbribable life, p. 166.

${ }^{90}$ see Caruth, Trauma: explorations in memory.

${ }^{91}$ see M.Heidegger, Hölderlin's bymn “The Ister” (Bloomington, Indiana: Indiana University Press, 1996), p. 75.

${ }^{92}$ see J.Young, 'Poets and rivers: Heidegger on Hölderlin's "Der Ister”", Dialogue 38(2), 1999, 391-416.

${ }^{93}$ see Heidegger, Hölderlin's bymn, p. 115.

${ }^{94}$ see B.Baillie, 'Capturing facades in 'conflict-time': structural violence and the (re)construction of Vukovar's churches', Religion, Violence, and Cities 17, 2013, 300-319.

${ }^{95}$ see J.C.Obert, 'The architectural uncanny: an essay in the postcolonial unhomely', Interventions: International Journal of Postcolonial Studies, 18(1), 2016, 86-106.

${ }^{96}$ see Campbell, Apartheid cartography; Edkins, Trauma and the memory of politics.

${ }^{97}$ see I.Andrić, The bridge over the Drina (London: George Allen \& Unwin, 1959); J.Wylie, 'A landscape cannot be a homeland', Landscape Research, 41(4), 2016, 408-416.

${ }^{98}$ see M.Heidegger, Poetry, language, thought (New York City, NY: Harper Collins, 1971).

${ }^{99}$ see Nancy, Being singular plural; Wylie, A landscape cannot be a homeland, p. 415.

${ }^{100}$ see Wylie, A landscape cannot be a homeland, p. 415; Nancy, Being singular plural, pp. 60-61.

${ }^{101}$ see Wylie, A landscape cannot be a bomeland.

${ }^{102}$ see M.Rose, 'Dwelling as marking and claiming', Environment and Planning D: Society and Space, 30(5), 2012, 757-771.

${ }^{103}$ see Wylie, A landscape cannot be a homeland. 
${ }^{104}$ see Nancy, Being singular plural.

${ }^{105}$ see A.Maddrell \& J.Sidaway (Eds.), Deathscapes: spaces for death, dying, mourning and remembrance (London: Routledge, 2010); P.Violi, Landscapes of memory: trauma, space, history (Pieterlen: Peter Lang, 2017); P.Williams, Memorial museums: the global rush to commemorate atrocities (Oxford: Berg, 2007).

${ }^{106}$ see Campbell, National deconstruction.

${ }^{107}$ see Wylie, A landscape cannot be a homeland.

${ }^{108}$ see Campbell, National deconstruction; Campbell, Apartheid cartography.

${ }^{109}$ see M.Blanchot, The writing of the disaster (Lincoln: University of Nebraska Press, 1995).

${ }^{110}$ see M.Blanchot, The space of literature (Lincoln: University of Nebraska Press, 1989); T.Väyrynen, 'Rethinking peace through the figure of Parrhesiastes: creating agonistic political space', International Journal of Conflict Engagement and Resolution, 2, 2013, 147-162.

${ }^{111}$ see Wylie, A landscape cannot be a homeland, p. 408.

${ }^{112}$ see Wylie, A landscape cannot be a homeland, p. 408.

${ }^{113}$ see C.Tilley, A phenomenology of landscape: places, paths, and monuments (Oxford: Berg, 1994).

${ }^{114}$ see Maddrell \& Sidaway, Deathscapes; K.Till, The new Berlin: memory, politics, place (Minneapolis: University of Minnesota Press, 2005); K.Till, 'Mapping spectral traces', in K.Till (Ed.), Mapping spectral traces (Blacksburg, VA: Virginia Tech College of Architecture and Urban Affairs, 2010), pp. 1-4.

115 see D.Drozdzewski, 'Using history in the streetscape to affirm geopolitics of memory', Political Geography, 42, 2014, 66-78.

${ }^{116}$ see Goldsworthy, Inventing Ruritania; Todorova, Imagining the Balkans; Žižek, The fragile absolute.

117 in order to conceal the location of mass graves, bodies were moved to smaller mass grave sites - at least sixteen reburial locations have been found so far by the Missing Persons Institute of Bosnia and Herzegovina.

${ }^{118}$ see M.Taussig, Walter Benjamin's grave (Chicago: University of Chicago Press, 2006).

${ }^{119}$ see Arsenijević, Mobilising unbribable life, p. 168.

${ }^{120}$ see W.Benjamin, On the concept of history (New York, NY: Classic Books America, 2009); Blanchot, The writing of the disaster.

${ }^{121}$ see Felman, The juridical unconscious, p. 13.

${ }^{122}$ see Baillie, Capturing facades in 'conflict-time'; M.Hirsch, Family frames: photography, narrative and postmemory (Cambridge, MA: Harvard University Press, 1997); M.Hirsch, The generation of postmemory: writing and visual culture after the Holocaust (New York, NY: Columbia University Press, 2012).

${ }^{123}$ see work on multidirectional memory, or when different histories and narratives of extreme violence confront each other in the public sphere, M.Rothberg, Multidirectional memory: remembering the Holocaust in the age of decolonization (Stanford: Stanford University Press, 2009).

${ }^{124}$ see Snel, The past is always in the present.

125 See A.Hemon, 'Trump: a war criminal in the making', Rolling Stone, February 29, 2016: https://www.rollingstone.com/politics/politics-news/trump-a-war-criminal-in-the-making-83735/

${ }^{126}$ see Suljagić, Postcards from the grave.

${ }^{127}$ see Moss \& Donovan, Writing intimacy into feminist geography; Pain, Intimate war.

${ }^{128}$ see S.Laketa, 'Geopolitics of affect and emotions in a post-conflict city', Geopolitics, 21(3), 2016, 661685; Young, The texture of memory.

${ }^{129}$ see Drakulić, S. A novel about the Balkans; Hemon, The book of my lives; Jergović, Sarajevo Marlboro; Obreht, The tiger's wife; Suljagić, Postcards from the grave; and D.Drozdzewski, S.DeNardi \& E.Waterton, 'Geographies of memory, place and identity: intersections in remembering war and conflict', Geography Compass, 10(11), 2016, 447-456. 
${ }^{130}$ see G.Didi-Huberman, Images in spite of all: four photographs from Auschwitz (Chicago, IL: University of Chicago Press, 2008).

${ }^{131}$ see Riding, Towards a cultural geopolitics.

${ }^{132}$ see Riding, The geopolitics of memory; Drozdzewski, DeNardi \& Waterton, Geographies of memory, place and identity.

${ }^{133}$ see Jeffrey, The improvised state.

${ }^{134}$ see K.Tilmans, F.vanVree \& J.M.Winter, Performing the past: memory, history, and identity in modern Europe. (Amsterdam: Amsterdam University Press, 2010).

${ }^{135}$ see Wylie, A single days walking, p. 235.

136 see N.Castree \& T.MacMillan, 'Old news: representation and academic novelty', Environment and Planning A: Economy and Space, 36(3), 2004, 469-480.

${ }^{137}$ see K.Olwig, 'Recovering the substantive nature of landscape', Annals of the Association of American Geographers, 86(4), 1996, 630-653.

138 see Riding, A new regional geography of a revolution.

${ }^{139}$ see Drozdzewski, DeNardi \& Waterton, Geographies of memory, place and identity; J.Wylie, 'The spectral geographies of W.G. Sebald', Cultural Geographies, 14, 2007, 171-188.

${ }^{140}$ see Till, The new Berlin.

${ }^{141}$ see Maddrell \& Sidaway, Deathscapes.

${ }^{142}$ see J.Dubow, 'Case interrupted: Benjamin, Sebald and the dialectical image', Critical Inquiry, 33(4), 2007, 820-836.

${ }^{143}$ see M.Rose, 'Back to back: a response to Landscape, absence and the geographies of love', Transactions of the Institute of British Geographers, 35, 2010, 141-144, p. 148.

${ }^{144}$ see M.Rose, 'Gathering 'dreams of presence': a project for the cultural landscape', Environment and Planning D: Society and Space, 24, 2006, 537-554, p. 538.

${ }^{145}$ see A.Y.Guillou, 'An alternative memory of the Khmer Rouge genocide: the dead of the mass graves and the land guardian spirits [Neak ta]', South East Asia Research, 20(2), 2012, 2017-226.

${ }^{146}$ see Nancy, Being singular plural; Nancy, The ground of the image.

${ }^{147}$ see Wylie, Landscape, absence, and the geographies of love.

${ }^{148}$ see Benjamin, On the concept of history.

${ }^{149}$ see Arsenijević, Mobilising unbribable life, p. 168.

${ }^{150}$ see Derrida, Spectres of Marx.

${ }^{151}$ see Arsenijević, Mobilising unbribable life.

152 see S.Craps, 'Learning to live with ghosts: postcolonial haunting and mid-mourning in David Dabydeen's “Turner” and Fred D’Aguiar's Feeding the Ghosts', Callaloo, 33(2), 2010, 467-475.

${ }^{153}$ see Arsenijević, Mobilising unbribable life.

${ }^{154}$ see K.Till \& A.K.Kuusisto-Arponen, 'Towards responsible geographies of memory: complexities of place and the ethics of remembering', Erdkunde, 69(4), 2015, 291-306.

${ }^{155}$ see D.Massey, 'Geographies of responsibility', Geografiska Annaler, 86(1), 2004, 5-18.

${ }^{156}$ see D.Rieff, In praise of forgetting: historical memory and its ironies (New Haven, CO: Yale University Press, 2016). 